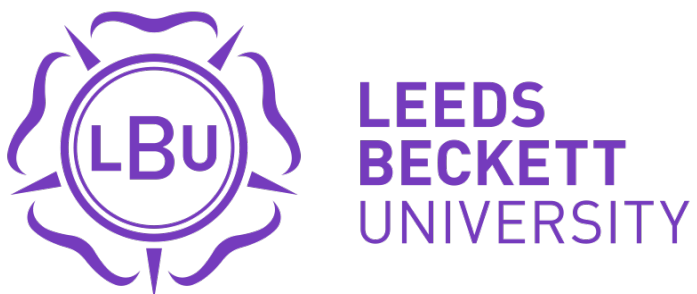

Citation:

Lamond, IR and Solano, E and Blotta, V (2020) Leisure activism and engaged ethnography: heterogeneous voices and the urban palimpsest. Leisure Studies. ISSN 0261-4367 DOI: https://doi.org/10.1080/02614367.2020.1724318

Link to Leeds Beckett Repository record:

https://eprints.leedsbeckett.ac.uk/id/eprint/6621/

Document Version:

Article (Accepted Version)

The aim of the Leeds Beckett Repository is to provide open access to our research, as required by funder policies and permitted by publishers and copyright law.

The Leeds Beckett repository holds a wide range of publications, each of which has been checked for copyright and the relevant embargo period has been applied by the Research Services team.

We operate on a standard take-down policy. If you are the author or publisher of an output and you would like it removed from the repository, please contact us and we will investigate on a case-by-case basis.

Each thesis in the repository has been cleared where necessary by the author for third party copyright. If you would like a thesis to be removed from the repository or believe there is an issue with copyright, please contact us on openaccess@leedsbeckett.ac.uk and we will investigate on a case-by-case basis. 


\title{
Leisure activism and engaged ethnography: Heterogeneous voices and the urban
} palimpsest.

\begin{abstract}
Studying the conflictualities between leisure activism, understood as participation in events of dissent as a nonwork-based activity, and those tasked with 'maintaining order', requires techniques that can work with diverse voices and contesting world views. However, many of the methods familiar to us in the social sciences risk reinforcing relationships of power that can undermine such inquiry. Drawing on the conceptual work of scholars from the global south and the global north, we examine approaches to protests as event, the construction of urban space and the performativity of violence, in two democracies: Brazil and the UK. From that we were led to conclude such research requires a less canonical approach. It is through the adoption of a more engaged ethnography, one that establishes horizontal relations between researchers and participants that are drawn from backgrounds reflecting such conflictualities, combined with an understanding of the process of research as more like that of an event, that the diversity of the heterogeneous voices associated with dissent, within an urban palimpsest, can be heard.
\end{abstract}

Keywords: leisure activism, protest, researcher/participant collaboration; global south; engaged research

Whilst political engagement, through participating in acts of protest, has long been one way people have chosen to use some of their leisure time, this century has seen participation in events of dissent, from online petitions to large scale public demonstrations, emerge as a global phenomenon (Gerbaudo, 2017). Yet, to date, discussion of such activist leisure has been limited (Pickard, 2017). In part this reflects the paucity of debate around those methods best suited to investigating both the manifestation and the representation of such events of dissent within leisure and event studies. Consequently, in this paper we seek to address the question; how are we to assemble a critical framework that can analyse events of dissent and leisure activism (Mair, 2002) within a democratic state? In order to do that, we argue, approaches and methodologies need to be developed that challenge many of the mainstays of traditional social science research. 
The manifestations of mass protest, whether localised or as part of a pan-global event of dissent, are commonly mediated through multiple discourses, a plurality of public spheres and a diverse range of information and communications technologies (Habermas, 1987). As such they are not intelligible through the application of a single narrative; consequently, a multidisciplinary approach becomes essential. Familiar, if somewhat safe, social science methods, such as interviews, surveys and questionnaires, are unable to grasp the complexity and nuance of the articulation of such mediated acts of leisure activism, alternatives are required (Lead author. In Press). Whilst the emergence of the digital social sciences and humanities attempt to address that complexity (Marres, 2017), the use of big data inclines towards describing networked relationships rather than trying to qualitatively understand the world views that are being contested. In order to develop a richer understanding of leisure activism, and such events, it is essential that we consider alternatives to, and adaptations of, the research toolkit many of us are familiar with.

The aim of this paper is to propose a research plan that could contribute to an inquiry into the multiplicity of narratives (the heterogenous voices of our title) associated with leisure activism, drawing on the experience of two democratic states, both currently experiencing uncertainty and instability; Brazil and the UK. In recent years the political establishment of Brazil has been rocked by a series of scandals around corruption, in part the result of the Lava-Jato investigation into links between governmental officials and several state-wide businesses. Meanwhile, in the UK, uncertainty and divisiveness has followed the 2016 referendum on its membership of the EU; resulting in three different Prime Ministers in three years. We will pursue our aim through two central tasks.

First, we will map out the theoretical landscape required by any methodology that wishes to investigate leisure activism and events of dissent. In that part of the paper we will discuss the relevance of critical event studies (CES) as a conceptual orientation. In addition, it is important to recognise that public protest, demonstrations etc. are comprised of relationships that involve the mobility and immobility of agents (both collective and individual) within spatial imaginaries. Such spatialities can, in Massey's (2010) terms, be “...imagined as articulated moments in networks of social relations" (p.7). Consequently, we will also reflect on how space is constructed through social relations. Discourses of dissent also evoke conflictualities around those imaginaries of space, our inter-relational connections to each other and our association with the institutions of the state, some of 
which become mediated as acts of violence (Zizek, 2008). The next step will thus be the conceptualisation of violence. Finally, as such conflictualities are either contested and/or amplified through the relationship between the media and protest, we will spend some time examining the complexity of that relationship.

Our second task will be to consider why tools familiar to social science research, common to many quantitative, qualitative and mixed methods, are ineffective in handling the imaginaries and conflictualities of activist leisure. This leads us to suggest that given the conceptualisation of 'event' within CES, if research is to grasp the complexities of leisure activism (Rose et al, 2018), public protest, and the mediation of events of dissent, it also needs to take on attributes that are more event-like. In conclusion, through a synthesis drawn from our discussion, we propose a new approach, one that challenges participants, researchers and how we construe research; we refer to this as an engaged ethnographic approach.

\section{Mapping the Theoretical Landscape around Dissent}

\section{Protest as Event}

The field of event studies can come across as a somewhat corporatist domain whose principal purpose is to support event-based tourism and the management of what Getz (2016) calls 'planned' events. One of the struggles within the field is an assumption that any answer to the question - To what does the term 'event' refer? - seems to narrowly focus on the economic. Spracklen \& Lamond (2016) argue to approach the study of events in this way reinforces its colonisation, along with a concomitant commodification of leisure, by a dominant neo-liberal hegemony. Consequently, such construals of 'event' and 'leisure' can hinder our capacity to challenge dominant relationships of power and oppression. CES construes 'event' differently. In place of the typology of events proposed by Donald Getz (Getz, 2016), it argues that space is relational (as suggested, for example, in Massey, 2004) and that the spatial aspects of 'events' are a palimpsest (Huyssen, 2003), where power inscribes, erases and re-inscribes commodified meaning, producing complex layered relationships of power and manipulation. Within such a field, leisure becomes contested.

So that we can better address the conflictualities in the mediation of the complexity of 'events' we must confront such contestation, and thereby gain a greater insight into how 
the event is being constructed. To do that, an understanding of the place of disruption/routine in the manifestation of protest, and the discourses of identity and othering, exposed through the manifestation of dissent, becomes a priority (Glynos \& Howarth, 2007). We propose to begin this by considering theories of space appropriate to the urban context in which many protests happen. Our focus is on public open space, such as those used in protest marches, occupations, and rallies, which have become closely associated with the imagery and iconography of the mediated manifestation of dissent (Rovisco \& Ong, 2016).

Urban space

Over several texts Lefebvre developed a detailed theory of spatiality (for example Lefebvre, 1991, 2004). He contends that there is a continuum of spatial production from simpler, 'natural', spaces to more complex ones that are socially produced and reproduced. In order to analyse any particular historical spatial moment, he argues, we require a threepart dialectic that combines an understanding of everyday practices and perceptions of space (le perçu), its representation (le conçu) and a grasp of the spatial imaginary of the time (le vécu). His philosophy has been highly influential, informing significant contributions to contemporary, critical, human geography. David Harvey, for example, acknowledges Lefebvre's influence on his own perspective (Harvey, 2004, 2012), which focuses on the appropriation of our own spatial imaginary by a dominant political economy; identified as neo-liberal globalised capitalism. Though less extensive in her recognition of Lefebvre's legacy, Doreen Massey (1992 and 2004) credits him with bringing to the fore the dynamics of everyday life to our understanding of space. It is worth noting that whilst Lefebvre's earlier work (Lefebvre, 1991) is cognizant of the role of spatial imaginaries, he downplays the palimpsestic significance of inscription, erasure and re-inscription of space. This is, at least partly, addressed in his last work, "Rhythmanalysis" (Lefebvre, 2004), in which patterns of repetition within social urban space take a higher profile.

In terms of understanding the manifestation and mediation of protest, we can view dissent as inhabiting a complex relational space of repetition and difference, where an event of dissent can highlight the way relationships of power are producing the lived spaces we inhabit (Harvey, 2012). From a Foucauldian perspective, this suggests that what is being highlighted, or exposed, are the discourses and regimes of truth that are constructing the 
space (Foucault, 2007). Consequently, one could argue, without protest/disruption we may not be able to apprehend those hegemonically constructed discourses of power as clearly.

\section{Violence and performativity}

Despite the threat of violence being a recurring theme in much of the literature associated with studies of protest and dissent (della Porta, 2008, 2015), the linking of that theme to its aesthetic and performative articulation is a relatively recent phenomenon (Zizek, 2009). The characterisation of the strategic use of property damage towards banks and global fast-food outlets by anti-globalisation and Black Bloc groups, has brought consideration of such themes to the fore (Solano et al, 2014). Black Bloc refers to groups of protesters, frequently conveying an anti-globalisation/anti capitalism message, who dress completely in black; this includes covering the face with a scarf, or ski mask, and sunglasses. Arguably, such attire combines personal protection with a means of steering the media's gaze towards the message rather than the individuals through which it is being conveyed.

This greater dimension of the aesthetic and performative aspects of violence in protest can be understood in relation to what scholars' call "expressive violence" (Block, 1977). According to Wieviorka, (1997), this kind of violence does not have to do with social or economic deprivation, but with reaction to denied subjectivities, the loss of the subjectivity, and to forms of violence experienced not only in the objective but the subjective world. It can encompass issues of identity construction manifested by and against specific groups and causes, such as ethnic and gender related violence, as well as violence against migrants, the elderly and so forth. "Expressive violence" has, as its social and historical background, the impact of neoliberalism in contemporary politics (Jinkings, 2007). Jinkings argues that as financial global markets redefine the role of the State, budgets for social expenses are reduced while the control of punitive instruments are extended; effectively criminalizing that which seeks to actively defy the logic of neoliberalism (Ibid). Even though the impacts may be quite different in Europe and South America, the main traits are similar: growth of social inequalities, violence, and corporate and state surveillance. For this reason, it is important to show what the violence means to all the parties involved.

In Brazil, this is a sensitive issue because greater parts of the population are not equal before the law; in regard to either individual, social or cultural rights (Kowarick et al, 2009). 
Throughout its history, Brazil's values of joy and miscegenation have naturalized and hidden aspects of violence and authoritarianism that have forged a highly hierarchized society in public and private (Chaui, 2013). In areas such as the Maré Complex in Rio de Janeiro, a State of exception is the public rule. Since the end of the 2018 Carnival, the city has been under a federal intervention decree. This has militarized public security forces and created an Extraordinary Ministry of Public Security. It has centralized power, and relativized individual rights, as a means of dealing with a supposedly "out of control" situation with regard to crime and violence. However, instead of lowering crime, it has ignited a series of murders involving police officers and residents, including Marielle Franco, a city deputy, and 14-year-old Marcos Vinicius (Smith, 2018).

According to Peas et al (2018) Brazil is, in effect, in an undeclared war between groups ostensibly funded through a direct or indirect association with organized crime. This creates marked sectors, where life is in a state of exception, producing homo sacer (Agamben, 1998); lives treated as worthless, that are not protected against violence or racism, that then become the main victims of State violence (Silva, 2014). This kind of violent and performative reaction becomes manifest through the justifications made by those who use "violent" methods in protests and public demonstrations (Solano et al, 2014). Those who adopt the Black Bloc tactics we mentioned earlier justify their actions by saying that their acts carry a symbolic and political message, one that needs some level of violence for it to reach the public sphere (Ibid). They argue that their acts are symbolically directed towards people through damage to goods and property; as such they should be seen as a means of articulating a protest against a perceived greater injustice (Ibid). Such political violence, they argue, is a way to contest a much more lethal State violence (Dupuis-Déri, 2014). It is a way to contest the State monopoly of violence and claim a legitimacy for smaller-scale and more private violence, in a form that targets an abuse of violence by the State. In these forms of dissent, the object is the message, and the performativity of that message carries a high symbolic value (Ibid).

Such identity driven protests produce a message of "symbolic-expressive violence" that sets itself against a Capitalist order (Juris, 2008); here we also see a relationship between symbolic and physical violence. There is an element of rage ('raiva' in Brazilian Portuguese) against the system; this is central to understanding this kind of violence. It is 
the use of force, understood as a response of rage and anger against the oppressions of inequality and exploitation. As Sullivan (2004) puts it - it is a "right to the rage" that becomes expressed as frustration, as a conscious feeling, integrated in the politicisation process and manifested through violent performances (Solano et al, 2014). Here Juris (2008) suggests how violent personal and identity denials lead to emotions that structure political vision and ways of contestation.

Another relevant aspect of such a theatrification of conflict, that appears as public transgression (Duvignaud, 1974), is the desire to reach public attention through mass media channels. In this sense, violent acts are also a way to "make the headlines". The human rights journalist Bruno Paes Manso recognized that the use of Black Bloc tactics were effective in getting media attention during the 2013 protests in Brazil (Solano et al, 2014). However, as the protests went on and the debate on the legitimacy of direct action grew, the insistence on using violence to get attention gradually weakened the protesters' claims in the Brazilian public sphere. As the media scholar Eugênio Bucci (2016) explains, an exaggerated claim for visibility in protests is part of a logic of the "spectacle" which has taken over the public spheres of western democracies. Following that logic, the visibility of the protesters' claims become somehow more important than the political claims themselves. It is through understanding the relationship between the protesters' claims and their media visibility that 'violence' can become the language and the "raw form" of protest (Bucci, 2016).

Media, protest and mediation of dissent

Studies of the relationship between media and protest usually construe the media as either a series of technological channels/institutions that are somewhat apart from, whilst affecting, political and social movements (Luhmann 2000), or as intervenient actors, amongst others, who exchange and facilitate the circulation of symbols, narratives and information (Krajina, 2017). Both approaches produce what Barker and Petley (2002) refer to as media effects, that are capable of engendering agenda setting. Such a perspective is similar to Strömback's conceptualisation of mediatisation (Strömback, 2014; Aelst et al, 2017), which argues that it is through the mediated logics of how power is made visible, resulting in increased fragmentation/polarization and inequality of political knowledge, that political events are determined. 
Reminiscent of Massey's approach to space (1992), Jesus Martin-Barbero proposes a focus of attention on the social relations within and around communication channels and industries; this he refers to as Mediation (Martin-Barbero, 1993, 2011). Such a position locates media as one amongst other actors present in political narratives and conflicts, rather than a neutral, manipulative and unidirectional political asset. In this view, the characteristics of the media and protests would be better captured outside the media; in less media-centric perspectives, that reflect and amplify the social relations of the media, and the role communication technology plays in contemporary western societies. Consequently, it can open up fresh opportunities for capturing empirical data. Ryan et al (2013) push this further; in "Walk, talk, fax or tweet", they argue that one needs to grasp the deep perceptions of participants through their narratives and storytelling, as it is through these that they will articulate reminiscent views and memories of past events. Following a process of thick description (Geertz, 1973; 2008) they believe storytelling can enable us to grasp people's worldviews and thus facilitate experiences of empathy or agonism between participants and researchers.

It is from such foundations that new research strategies can be established. Instead of asking participants directly what they think, or monitoring covertly their behaviour, techniques that build a bridge of shared respect and trust between participants and researchers, as true research collaborators, can enable participants to share their personal narratives and memories, which can then relate back to relevant topics in the research. However, in order to progress and develop new techniques we first need to consider those methods more familiar, if safe, to a leisure studies/sociological study of protest and dissent, evaluate their effectiveness and assess what, if anything, can be drawn from them.

\section{Familiar social science approaches to the study of protest}

The more common and familiar approaches used in social science research tend to operate around a binary of qualitative and quantitative methods that functionally connect to construals of subjectivity and objectivity. Even though there is an increased use of methods that combine the poles of that binary, they do not significantly challenge it. Such triangulatory tactics are reliant on an assumption that research findings are grounded in a neutral realism to which participants and researchers have a shared access (Robson \& McCartan, 2015). Here we hit a significant difficulty when working with participants who are 
either engaged in leisure activism or its suppression. The lead author et al (2015) suggests activism, as an aspect of serious leisure, is a form of self-othering, one that constitutes a public sphere in contestation to that of the imaginary articulated by a dominant hegemony. It is the differences in world views, and their associated principles of what constitutes truth and evidence, that sustains that contestation (Weible \& Sabatier, 2006). What this means, in practice, is that those associated with dissent, whether they be engaged in protest or its suppression, are often embedded in a discourse where the manifestation of power relations can obfuscate their contribution to research. Colloquially, it could be said that their public sphere produces a 'comfort zone' that establishes the boundaries within which participants are or are not prepared to participate. Consequently, while we may obtain some insight into a dissenting worldview, this will either reinforce our own position, because it is a cause with which we are in sympathy, or prove problematic to decode successfully, as it sits in a worldview for which that sympathy is absent. Even potential neutrality on a cause is insufficient, as this may also obscure the researcher's apprehension of the participants' ways of being in, and knowing, their social world.

Such difficulties strike at the heart of what constitutes qualitative and the quantitative data and grasping what objectivity and subjectivity mean, as such binaries obviate an understanding of what it means to protest and what the mediation of dissent is doing to the articulation of the manifestation of protest. Alternative methodologies are required if we want to gain insight into these public spheres and grasp the complexity of activist leisure, events of dissent, and their mediation. In order to do that we must begin by looking beyond the relatively simple frameworks of interview, questionnaire, survey etc.; tools that have become the default for a lot of sociological inquiry. An exhaustive review of alternatives is outside the scope of a research paper. We have thus focused on two promising examples, from which we seek to learn: Group Dialogic Approaches, and Photo/Artefact elicitation techniques. Both have informed the research approach we will go on to propose. However, to demonstrate that connection it will also be important to consider the place of the researcher within them.

\section{- Group Dialogic Approaches}


One way of addressing the issues we have raised would be to approach the topic polyphonically. By that we mean the use of multiple researchers as well as group-based participation. It could be argued that by having multiple researchers, drawn from diverse cultural-political-economic backgrounds, and groups of participants also pulled from different backgrounds; that the differences could be used to facilitate a heterogeneity of voices contributing to the data. In something approaching more familiar social science language one might argue that the diversity permits some form of neutrality to be realised, thereby allowing objective data to emerge. There are, however, problems with such a proposal. At a practical level, how confident can we realistically be that any mix of people in a group would be sufficient to produce a neutral discussion? And, besides, what do we mean by 'neutrality'? If we are seeking some level of conviviality between participants, the heterogeneity we are trying to examine would be undermined, thus jeopardising our capacity to examine how a dominant cultural-political economy mediates the manifestation of protest? In addition, there is a strong tradition in social theory (for example Garfinkel, (1999 [1967]) that would suggest such dialogic approaches always contain performative elements that may alter the interactions between the participants. Thus, whilst some form of group discussion may be advantageous, we must be mindful of its performative characteristics and establish some techniques to mitigate those difficulties.

If we wish to obtain an understanding of the experience of leisure activism and events of dissent that are rooted in the lives of people intimately involved in, and associated with, protest, some of which will involve aspects of violence, one must also account for the manifestation of trauma in its articulation. In such circumstances group storytelling can facilitate the elicitation of elements of the subjective expression of lived experience. As we mentioned earlier, Ryan et al (2013) argue that such narratives are neither a perfect recollection of the facts nor a dramaturgical/fictional representation of the events. However, they do present a space through which participants, as co-researchers, affectively connect to the past. Liao, in her description of cultural activism in Taiwan (Liao, 2015) describes the process like this:

"During the performance, the spectators are experiencing the process of interpreting and decoding the past with the present historical context. The 
narrative of the past is no longer simply a story told. It is... 'a cult enacted'; the experience of time and space is not unequivocally of the past but of a 'metaphysical present'." (p.43)

In order to develop a research plan that can support an inquiry into the multiplicity of narratives associated with leisure activism, we need to establish strategies that can evoke, these representations and performances of past events in group dialogue. If the familiar format of a group dialogic approach potentially inhibits our capacity to develop suitable data, something is required to disrupt that research framework. What seems to be required, therefore, is the gap between participant and researcher, within the research process, must be contested; framing the research activity as an event. This, however, needs to be handled with considerable care and sensitivity. When people are attempting to articulate root concepts around who they are, how they grapple with their orientation to others, and the articulation of their being-in-the-world, they can be highly vulnerable and potentially volatile. How we address such matters is something we will handle in more detail later. For now, it is important to carry forward the idea that participation in research that is serious about developing a richer understanding of activist leisure and the mediation of protest, needs to be exhibit a more evental character. In the next section we consider how photo and artefact elicitation can carry this evental character.

\section{- $\quad$ Photo and Artefact-Elicitation}

In recent years use of photo-elicitation and artefact elicitation, where photographic images or objects are used to stimulate a discussion or form part of an interview, have seen substantial growth as qualitative research methodologies. Such approaches have merit and may be of value in protest research, though they do come with concomitant challenges to the researcher.

The first person to propose using photography as a means of eliciting data from interview participants was John Collier (1967). His approach still forms the backbone of most approaches to photo-elicitation. Recently Feigenbaum et al (2013) have used analogous techniques as part of protest-camp research. In their study, photographs were gathered by the researchers and used to stimulate otherwise unstructured "Camp Fire 
chats" (p25) with protest camp occupants. The only example we found of the use of photographs drawn from participants, within social movement studies, was in Adamoli's study of activist uses of photographs on social media (Adamoli, 2012). However, that research primarily used photographs as a source of secondary data, and although some elements of photo-elicitation were employed, its use was relatively minor.

Passing over the selection and curation of images to be used to the participants requires the researcher to give up a degree of control. It establishes participants as coresearchers in the project. Whilst they may not be engaged in all aspects of the programme, the giving up of a key element of the research activity to participants both enhances trust and raises the possibility that the research may not follow the pre-thought pathway that the lead researcher initially intended. Listening rather than interpreting thus becomes the group lead's primary role. A similar situation can occur with the lesser used approach of artefact elicitation. First developed by Barrett \& Smigiel (2003), they used artefacts to stimulate interviews around familial participation in the arts, in Australia. Whilst we found no instances of the use of artefacts in research associated with protest, activism, or events of dissent, it does appear to be an approach that might be fruitful as a supplement to group dialogic approaches, within the field. Lead researcher selection of imagery/objects may skew findings, not simply because of some implicit presupposition that connects them but because it also robs participants of ownership of material that is central to their own connection to the issue being addressed by the research. Trusting the participant, being open to what they bring and the data they generate through discussing their artefact with others, pushes the researcher into a potentially vulnerable position. It is, however, a position that has the potential to produce participant data that is more honest, and closer to the topic under investigation, than could be generated otherwise.

So far, we have placed the participant at the forefront of our discussion, let us now turn to focus on the researcher.

\section{Researcher position}

As Jarvie (1969), in his work around participant observation in anthropology, was to note, participant observation always revolves around a clash of roles; friend/stranger, participant/observer, insider/outsider. Whilst Jarvie suggests the researcher can take a 
unique and enriched space that is neither insider nor outsider, others, such as those developed by disability, feminist, queer, and critical race theorists, have argued there is a central problematic here that needs to be addressed (Toy-Cronin, 2018). Issues around the binary of insider/outsider do, at least anecdotally, seem to resonate with research into protest and social movements. Some of this is understandable. Police and security services have, historically, infiltrated activist groups (Uysal, 2016), so some level of scepticism around those asking a lot of questions is important for activist and social movement survival. The tension between the academic and the activist, however, even within the study of protest and dissent, may be more in the affect of the researcher. Whilst bias towards a position is always likely to be present, the discursive practices of critical scholars can be fluid and flexible enough to accommodate a degree of contestation in the ideas and world-views being investigated (Eschle and Maiguashca, 2006).

\section{- $\quad$ Autoethnography as a way of accessing experiences of dissent}

Earlier we suggested that working with participants as partners in the development of knowledge formation may be part of a way forward. We suggested that such an approach requires researcher vulnerability; exposing them as present in the research, not just a prospector for new data. Open and honest autoethnographic co-presence may thus provoke more authentic perceptions from participants as it allows them to talk about themselves, and their personal experiences, without artificial rationalisation. In this sense, it has both analytic and evocative potentials. Through the narrative exchange of their diverse personal experiences, the research approach becomes eventalised. It thus permits the transformation of the researcher and participants, throughout the research process, through trust and shared vulnerability. Autoethnography that uses participant-led elicitation tools can result in the researcher relaxing an excessive grip on the research agenda, increasing the potential for participant engagement. That 'relaxation' allows feelings and narratives to surface, with the intention to push beyond easy realities. As an approach it is risky but, arguably, necessary to reach towards an otherwise unidentified unknown.

Goodall (2000) argues autoethnography can enable "...the creation of narratives shaped by the writers personal experiences, within a culture" (p.9). According to Lockford (2004), in order to promote an autoethnographic research setting, researchers and 
participants need to "strip themselves" (p.9) emotionally and intellectually, opening a way for evocations:

\footnotetext{
"I attempt to situate my readers in a visceral connection with the experiences I describe. The principle that governs the autoethnography is that evocation leads to deeper comprehensions than traditional research, where one is informed about ideas." Lockford (2004, preface).
}

Reed-Danahay (1997) suggests the autoethnographic experience transcends the limits between experience, perception and thought, of the individuals. According to Neumann (1996), it “...democratizes the representational sphere of culture by situating the experiences of individuals in tension with the dominant expressions of discursive power" (p.189). By confronting the individual's interpretation of their past actions, it becomes a strategy that contests non-hegemonic and hegemonic discourses. As Tierney (1998) states; “...autoethnography (confronts) ...dominant forms of representation and power, with the intentions of claiming, through self-reflexive answers, representative spaces that have been marginalized in the frontiers" (p.66).Autoethnography thus allows the researcher to access different levels of consciousness, as one "...look[s] more deeply at intersections between self and other" (Ellis, 2004 p.37). It is a mixture of investigation, literature and method that aims "...to connect the autobiographical and personal to the cultural, social and political" (Ibid, p.XIX), which leads us to also think about the importance of the researcher's personal life story and narrative.

However, autoethnography, as a non-canonical approach, is criticized by many ethnographers who argue that it cannot produce more "authentic" perceptions by the participants (Freeman, 2011). Because of its "self-referential" character, some ethnographers see it more as way of provoking narcissist and essentialist narratives (Valdez, 2008). To a considerable extent such criticisms are mitigated through the supplementing of autoethnography with the elicitation techniques proposed earlier. Through engaging with participants as co-researchers, within a space where different actors involved or associated with activist leisure can engage in honest and open dialogues, as equals, a quality often missing from developing a richer picture of dissent may be allowed to emerge. We will now consider, in more depth, just what is entailed by such engaged research. 
We have established that the role of the researcher interested in activist leisure and protest needs to confront several questions. These include the place she occupies in the research, how to elaborate the knowledge it enables, and the role of that knowledge. Traditionally, the answers to these dilemmas have been that the researcher must differentiate herself from the "object" researched, using her distance from it to produce intellectualized knowledge. This is different from the engaged research we propose, the purpose of which is to understand other possibilities and, fundamentally, to think of the political commitment of the research activity. As such, it surpasses the classic division between theory and practice and the idea that scientific knowledge is separate from social reality. We can draw lessons here from congruous social scientific research in Latin America.

Since the 1960s, Latin America has faced a debate about the role of engaged research in the social sciences (e.g. militant research by some South American academic/activists: see Solano et al, 2014) . In a continent previously colonized by European standards, politically, economically, and in the production of knowledge, Latin American universities reproduced historical asymmetries between centre and periphery, imposing Eurocentric, capitalist, and rationalist approaches to the scientific domain (Quijano, 2000). However, given its Cartesian separation between knowledge and its objects, such Eurocentric and rationalist approaches have become vehicles for the reproduction of injustice and violence.

Alternatively, the work of Paulo Freire (Freire, 2015) can play a fundamental role in the construction of the theoretical base of engaged/activist research methods, as it proposes a horizontal relationship between researcher and participant; one that is founded on listening and shared learning, rather than the 'researcher' harvesting 'knowledge' from the other. As we have shown, traditional approaches place the researcher in a hierarchical position of superiority, smothering their participants by placing them in a position of subalternity which reproduces historically unequal relationships of power. Counter to this, engaged research can be built horizontally, so as to serve the participants involved (Méksenas, 2006). Mexican educators Rodriquez \& Hernandez (1994), point out that one of the characteristics of this type of research is that the traditional relation between subject and object must be progressively transformed into a relation between subject and subject. 
The results can lead to new interactions, partnerships, reciprocal learning processes and friendship.

The Brazilian scholar Breno Bringel (Bringel \& Varella, 2016) argues that we must rupture the dichotomy between the subject and the object of research if we are to generate and consolidate networks of trust; creating spaces of permanent convergence between universities and social movements. This allows for the realisation of engaged research as a space of knowledge production where heterogenous voices of public policies and social movements meet. The central debate around engaged research is how such knowledge can serve the communities, groups, mobilisations, studied, and contribute to popular transformation. A Freirean orientation that values participants as co-researchers can produce politically engaged knowledge (Freire, 1973). Whilst it does not reject methodological rigor or intersubjective control and unconstrained openness, it adds a commitment to concrete change, particularly directed towards the researcher/research participant relationship.

An important dimension of engaged research is its focus on the themes/agendas relevant to those drawn into the study. It approaches normative social struggles by highlighting the participant's needs, and considers their centrality throughout the research planning process, rather than framing them only as the object of the researcher's academic gaze (Baptista, 2006). As we saw in our discussion of autoethnography, this can go beyond the interview or focus group to include sharing images, artefacts and literature, the interpretation of results, and supporting the project's final evaluation. Drawing of Freire's work on critical consciousness (Freire, 1973), engaged research need not end with the completion of the study. Communication between researchers and participants can persist, going beyond the study's conclusion as knowledge production. A process of continuous feedback between the 'researcher' and the 'research participant' can continue to provide tools for future dialogue, enabling decision making between the researchers, participants and social groups involved (Barker and Petley, 2002).

Brandão (1983) argues that we only know something about social life, in depth, when there is a straight and direct involvement between the lives of researchers and participants. He goes on to argue that there is a need for an attitude of coexistence and reciprocity. Research around activist leisure and protest events (engaged research) seeks to promote participation through the recognition of the other (acknowledging heterogenous voices), 
supporting interaction with political intentions and the development of proposals, through a commitment to social change. It must aim to produce a transformation in the research participant(s) and the researcher(s) as both are considered political subjects that need to step out of their comfort zones. In Haraway's (1997) words, in order to provoke transformation, knowing must be "think-with" work and not "think about" work (p.36). It is thinking with the other, which denies there can be thought separate from the societal realm.

\section{Concluding remarks}

The purpose of our paper was to develop a method that could inquire into the multiplicity of narratives associated with leisure activism, drawing on the experience of two democratic states currently experiencing uncertainty and instability.

We began by problematising the topic, approaching our reflections on protest from a perspective of leisure activism (Mair, 2002; Rose et al, 2018) and CES (Spracklen and Lamond, 2016), progressing from there we addressed the themes of the social construction of urban space; the performativity of violence and, finally, the relationship between media and dissent. We concluded that those research approaches most familiar to us in the social sciences were insufficient when considering the heterogenous voices articulated in the urban palimpsest. To address those concerns, we needed to think about research as a collaborative endeavour between 'researchers' and 'participants', one where respect and trust could be nurtured, and grow; a process that could take on aspects of the evental.

In the second part of our paper we considered several prospective candidates that, whilst not as universally approved as those we argued were more familiar approaches, went some way to addressing the requirements we had identified. Elements of a group dialogic approach, and the use of photo/artefact elicitation tools, were found to go a considerable way to confronting the issues we had raised. However, they risked reproducing the power dynamic of those more familiar techniques. To undermine those systemic power relationships the place of the researcher had to be more closely interrogated; this was achieved through a consideration of how autoethnography may give us insight into the experiences of dissent. While we recognised that many in the social sciences did not regard autoethnography as canonical, we argued that combining such an approach with the eventalisation of the research process, with the transfer of key elements of the inquiry to 
the 'participants', could open up fruitful new pathways which can deepen our understanding of protest, events of dissent, and leisure activism. We called that approach engaged research. Whilst we acknowledge a strong debt to the 'militant research' perspective we chose the adjective engaged to emphasise the importance of building relationships, even amongst actors traditionally seen as opposed. By eventalising the research, providing a space where openness was welcomed, we were able to encourage greater trust, conversation and connection.

Listening and sharing have been a key part of the growth and evolution of this project and this paper. The authors are drawn from both the global south and the global north. Without the development of friendship, trust, and genuine interest in the thoughts, perspectives, experiences, and ideas of each other, this paper would not have happened. It is a tapestry, woven by our own heterogenous voices.

\section{$\underline{\text { References }}$}

Adamoli, G. C. E. (2012). Social media and social movements: A critical analysis of audience's use of Facebook to advocate food activism offline. Online at: $<$ https://diginole.lib.fsu.edu> Accessed: 01.08.2018

Agamben, G. (1998) Homo Sacer: Sovereign Power and Bare Life. Stanford, Stanford University Press.

Baptista, T. (2006). The most Portuguese village in Portugal: tradition in the age of its technical reproducibility. Online at <https://run.unl.pt> Accessed: 16.06.2018

Barbero, J. M. (1993). Communication, culture and hegemony: From the media to mediations. London, Sage.

Barker, M., and Petley, J. (2002). III Effects: The Media Violence Debate. Abingdon, Routledge.

Barrett, M. S., \& Smigiel, H. M. (2003). Awakening the 'Sleeping Giants'?: The arts in the lives of Australian families. International Journal of Education \& the Arts, 4(4), 1-9.

Bhabha, H.K. (1994 [2004]) The Location of Culture. Abingdon, Routledge.

Block, R. (1977) Violent Crime: Environment, Interaction, and Death. Lexington, D.C. Heath. Brandão, C.R. (1983). Os caipiras de São Paulo (Vol. 75). São Paulo: Editora Brasiliense. 
Bringel, B., \& Varella, R. V. S. (2016). A pesquisa militante na América Latina hoje: reflexões sobre as desigualdades e as possibilidades de produção de conhecimentos. Revista Digital de Direito Administrativo, 3(3), 474-489.

Bucci, E. (2016) A forma bruta dos protestos: das manifestações de junho de 2013 à queda de Dilma Rousseff em 2016. São Paulo, Editora Campanhia das Letras.

Cammaerts, B., Mattoni, A., \& McCurdy, P. (Eds). (2013). Mediation and Protest Movements. Bristol, Intellect Books.

Chaui, M. (2013). Democracia e Classe Média. In Conferência realizada no Centro Cultural Oscar Niemeyer, Projeto Café de Ideias.

Collier, J. (1967) Visual Anthropology: Photography as a Research Method. New York: Holt, Rinehart and Winston.

Deleuze, G. (2014) Difference and Repetition. London, Bloomsbury Academic.

Della Porta, D. (2008) Research on social movements and political violence. Qualitative Sociology. 31 (3), 221-230.

Della Porta, D. (2015) Social Movements in Times of Austerity. Cambridge, Polity Press.

Dupuis-Déri, F. (2014). Who's afraid of the Black Blocs? Anarchy in action around the world. Trans. L. Lederhendler. Oakland, PM Press.

Duvignaud, J. (1974) Sociologia Guia Alfabetico. (nl),Forense.

Ellis, C. (2004). The ethnographic I: A methodological novel about autoethnography. Maryland, AltaMira Press.

Eschle, C., \& Maiguashca, B. (2006). Bridging the academic/activist divide: feminist activism and the teaching of global politics. Millennium, 35(1), 119-137.

Feigenbaum, A., McCurdy, P., \& Frenzel, F. (2013). Towards a method for studying affect in (micro) politics: The campfire chats project and the occupy movement. Parallax, 19(2), 21-37.

Foucault, M. (1986) Of other spaces. Trans. J. Miskowiec. Diacritics. 16(1), 22-27

Foucault, M. (2007) Security, Territory, Population. Lectures at the College de France: 19771978. Trans. G. Burchell. Basingstoke, Palgrave Macmillan.

Freeman, J. (2011). Solipsism, self-indulgence and circular arguments: Why autoethnography promises much more than it delivers. Journal of Arts \& Communities, $3(3), 213-227$.

Freire, P. (2015). Pedagogy of indignation. Abingdon, Routledge. 
Freire P. (1973) Education for critical consciousness. London, Bloomsbury Publishing. Garfinkel, H. (1999 [1967]) Studies in Ethnomethodology: Social and Political Theory). Oxford, Blackwell Publishing.

Gerbaudo, P. (2017) The Mask and the Flag: Populism, Citizenism and Global Protest. London, C Hurst \& Co.

Getz, D. (2016) Event Studies: Theory, Research and Policy for Planned Events. ( ${ }^{\text {rd }}$. Ed.) Abingdon, Routledge.

Glynos, J. \& Howarth, D. (2007) Logics of Critical Explanation in Social and Political Theory. Abingdon, Routledge.

Goodall Jr, H. L. (2000). Writing the new ethnography. Maryland, AltaMira Press.

Haraway, D.J. (1997) Feminism and the Technosphere. New York, Routledge.

Harvey, D. (2012) Rebel Cities. London, Verso Books.

Headland, T.N., Pike, K.L. \& Harris, M.E., (1990) Emics and etics: The insider/outsider debate. Conference proceedings: 87th Annual Meeting of the American Anthropological Association in Phoenix, Arizona: Nov 19, 1988.

Huyssen, A. (2003) Urban Palimpsests and the Politics of Memory. Stanford, Stanford University Press.

Jarvie, I. C. (1969). The problem of ethical integrity in participant observation. Current Anthropology, 10(5), 505-508.

Jinkings, I. (2007). Sob o domínio do medo: controle social e criminalização da miséria no neoliberalismo. Online at: <http://repositorio.unicamp.br> Accessed: 23.02 .2019

Juris, J. S. (2008). Networking Futures: The Movements against Corporate Globalization. Durham, Duke University Press.

Kowarick, L., Gurza Lavalle, A., Marques, E., Moya, M. E., Moura, F., \& Gervaiseau, H. (2009). A cidade de São Paulo sempre foi um tema importante para você. Como foram...[Entrevista]. Retrato de grupo: 40 anos do Cebrap.

Krajina, Z. (2017). Media and Social Solidarity: Assessing Dayan and Katz's 'Media Events'. Medijske Studije, 3(5) 3-17

Latour, B. (2004). Why has critique run out of steam? From matters of fact to matters of concern. Critical inquiry, 30(2), 225-248.

Lead author et al (2015)

Lead author (in press) 
Lefebvre, H. (1991) The Production of Space. Trans. D. Nicholson-Smith. Oxford, Blackwell's. Liao, D.Y. (2015) Space and memory in the Huashan Event. In I.R. Lamond and L. Platt. (Eds) Critical Event Studies: Approaches to Research, pp.109-130. London, Palgrave Macmillan.

Lockford, L. (2004). Performing femininity: Rewriting gender identity. Maryland, AltaMira Press.

Mac Gregor, H. C. (2013). 1 Necropolitica la politica como trabajo de muerte. Ábaco, (78), 23-30.

Mair, H. (2002) Civil leisure? Exploring the relationship between leisure, activism and social change. Leisure/Loisir 27 (3-4), 213-237

Marres, N. (2017) Digital Sociology: The Reinvention of Social Research. Cambridge, Polity Press.

Massey, D. (1992) Politics and Space/Time. New Left Review. 196, pp.65-84

Massey, D. (2004) Geographies of responsibility. Geografiska Annaler. Series B. Human Geography, $86(1), 5-18$

Meksenas, P. (2006). Sociedade civil estado: Contradicoes do espaco publico e interesses democraticos. Revista Linhas, 7(2). Online at: <http://revistas.udesc.br> Accessed: 16.06.2018

Mesquita, A. (2015) Esperar não é saber: a arte entre o silêncio e a evidência. São Paulo. Ed. do autor.

Minayo, M.C.D.S., \& Sanches, O. (1993). Quantitativo-qualitativo: oposição ou complementaridade?. Cadernos de saúde pública, 9, 237-248.

Neumann, M. (1996). Collecting ourselves at the end of the century. In C. Ellis and A.P. Bochner (Eds) Composing ethnography: Alternative forms of qualitative writing. Vol. 1, pp.172-198.

Pickard, S. (2017) Politically engaged leisure: The political participation of young people in contemporary Britain beyond the Serious Leisure model. Online at: <https://angles.saesfrance.org/index.php?id=1083> Accessed: 21.02.2019

Quijano, A. (2000). Coloniality of power and Eurocentrism in Latin America. International Sociology, 15(2), 215-232.

Reed-Danahay, D. (1997). Auto/ethnography. New York: Berg. 
Robson, C. \& McCartan, K. (2015). Real World Research. 4th Ed. Chichester: John Wiley \& Sons Ltd.

Rodriquez, G.L. \& Hernandez, L. (1994) Investigación participativa. Madrid, Centro de Investigaciones Sociológicas.

Rose, J.; Harmon, J. \& Dunlap, R. (2018) Becoming political: An expanding role for critical leisure studies. Leisure Sciences. 40 (7), 649-663

Rovisco, M. \& Ong, J.C. (eds.) (2016). Taking the Square: Mediated Dissent and Occupations of Public Space. London: Rowman \& Littlefield Int.

Ryan, C., Jeffreys, K., Ellowitz, T., \& Ryczek, J. (2013). Walk, talk, fax or tweet: Reconstructing media movement interactions through group history telling. In B. Cammaerts; A. Mattoni, P. McCurdy (eds) Mediation and Protest Movements. Bristol, Intellect Books. pp.133-158.

de Silva, J. (2014). Valour, violence and the ethics of struggle: constructing militant masculinities in Sri Lanka. South Asian History and Culture, 5(4), 438-456.

Smith, C. (2018) Lingering trauma in Brazil: Police violence against black women. NACLA Report on the Americas. 50 (4), 369-376.

Soja, E.W. (1996) Thirdspace: Journeys to Los Angeles and other Real-and-Imagined Places. Oxford, Blackwell.

Solano, E., Manso, B.P., \& Novaes, W. (2014). Mascarados: a verdadeira história dos adeptos da tática Black Bloc. Sao Paulo, Geração Editorial.

de Souza Chauí, M. (2013). Manifestações ideológicas do autoritarismo brasileiro. Editora Fundação Perseu Abramo.

Spracklen, K. \& Lamond, I.R. (2016) Critical Event Studies. Abingdon, Routledge.

Strömbäck, J. (2014). Greater media choice risks creating an information gap between 'news-seekers' and 'news-avoiders'. LSE European Politics and Policy (EUROPP) Blog. Online at <http://eprints.Ise.ac.uk> Accessed 23.02.2019

Sullivan, S. (2004) We are the heartbroken and furious! Engaging with violence and the (anti)globalisation movement(s), University of Warwick Centre for the Study of Globalisation and Regionalisation. CSGR Working Paper 123/03

Thomassen, J., 2015. What's gone wrong with democracy, or with theories explaining why it has? In T. Poguntke, T.; S. Rossteutscher, R. Schmitt-Beck, and S. Zmerli, (Eds) Citizenship and Democracy in an Era of Crisis. pp.56-74. Abingdon, Routledge. 
Toy-Cronin, B. (2018). Ethical Issues in Insider-Outsider Research. The SAGE handbook of qualitative research ethics. This also needs editors, page numbers, and publisher with place published.

Tierney, W. G. (1998). Life history's history: Subjects foretold. Qualitative inquiry, 4(1), 4970.

Uysal, A. (2015). Doctrine du maintien de l'ordre et encadrement policier des manifestations en Turquie. Revista de Estudios Internacionales Mediterráneos, (17).

Valdez, C. G. (2008). Expresión autoetnográfica: consciencia de oposición en las literaturas de los Estados Unidos. Revista de Antropología social, 17. 73-94

Weible, C.M. and Sabatier, P.A. (2006) A guide to the advocacy coalition framework. In F. Fischer, \& G.J. Miller (Eds) Handbook of Public Policy: Theory, Politics, and Methods, pp.123-136. Florida, CRC Press.

Wieviorka, M. (1997). The new paradigm of violence. Tempo social, 9(1), 5-41.

Zizek, S. (2009) Violence. London, People Books Ltd. 